\title{
LAND MANAGEMENT GROUNDED IN SOCIAL SOIL Galician land banking in context
}

\author{
Elsa Coimbra
}

\section{Introduction}

In the following pages we consider Galicia, a region in the Iberian northwest, and see how a specific policy under the profile of Galician Land Bank aims to tackle land use predicaments that are specific but in no way limited to the Galician borders. Across the globe, land use, and rural land in particular, offers a sharp reflection of the obstacles, demands, and possible solutions for many of today's social and environmental concerns, such as resource allocation, food and energy dilemmas, amongst other issues. To that extent, land policies are not only interesting objects for social theoretical scrutiny but arguably represent pressing and valuable material for applied research. Through placing this specific policy in context we hope to raise awareness on the need to probe and question how land policies in Galicia and elsewhere are being implemented in ways that might prove useful to a broad spectrum of readers involved with land issues, from scholars of rural sociology to policy makers and land managers, both inside and outside Galician borders.

Land banking is a well-established management instrument, and has been used in different countries to deal with a variety of issues such as land resettlement and, most typically, land fragmentation. Land banking has been defined as "public or publicly authorized acquisition of land to be held for future use to implement public land policies" (Strong, in Van Dijk and Kopeva, 2006: 290). Frequently, land banking uses publicly owned land as a land fund. Similarly, the state also purchases and resells land. In this way, government can exert its influence on different policies with spatial impact, be they in infrastructural, environmental or agricultural matters. It is a strategy for intervention in private affairs of land market and land tenure, whereby, according to Van Dijk, "a government does not have to manipulate or control actors but can more directly change land ownership relations within a certain area" (Van Dijk and Kopeva, 2006: 291).

In the realm of research, land banking does not seem to be a particularly prolific theme for in-depth study. There have been, however, some recent contributions to analyzing land banking in relation to specific contexts, with their social and political contingencies, such as those in Central Europe presented by author Terry Van Dijk. Similarly, direct interest in exploring the potentials of the policy's application is visible through the FAO's recurrent interest in the subject along with projects with wide international scope, such as Farland (Future Approaches to Land Development). ${ }^{1}$ 
The contribution from the present article stems from applied research; its analysis strives to ground land banking as a multi-level governance initiative in its context, seeking to fill in the details of the twists and turns of its implementation. Such practical approach has found useful support in those theoretical frames that highlight the interplay between social systems of rules and the concrete situational conditions where they take place (Burns and Flam, 1987; Ostrom, 2003). Social rule system theory in particular can provide a solid framework to understand how context is able both to enable and block the implementation of certain rule systems. Analysis also made use of theoretical tools provided by Burns and Stöhr (s/d), namely its model of the architecture of governance systems with some of their conceptual components and inter-linkages.

In this regard, two basic building blocks were considered: (1) a social organizational complex, and (2) a problem-solving complex. In the first case, we have identified how a particular class of designated agents comes about in land banking (public authorities, stakeholders), their relationship, and roles in making collective decisions. In the second instance, we have identified how land banking is implemented according to the main agent's definition of relevant problems or issues, the goals or priorities relating to the problems, the causal linkages, and strategies to solve or deal with problems. The analysis of such elements also took into consideration key governance issues, such as power arrangements, various agents (including different stakeholders) with their multiple knowledges and rationalities and different and often conflicting interests among those involved and affected by such policy.

Overall, this paper is focused on the bank's governance strategy and how it is articulated to its context, that is to say, how land banking in Galicia simultaneously answers and is being questioned by its territory and society. Analysis is coupled by a general assessment of the governance strategy, a review that measures land banking in accordance to what is one of the main challenges of modern governance: being able to coordinate and integrate different regulatory mechanisms, diverse agents, and differing interests. Hopefully, this paper contributes to such pursuit, with research serving as a vehicle for awareness and communication of the links between people and policies, administrators and the public. Arguably awareness and receptivity are useful if not wise navigation stances for the successful implementation of land policies such as land banking, particularly in times of perceived uncertainty, towering challenges, and continuous change.

\section{Methodology}

The present paper draws information from a two-and-a-half-year assessment project which took place roughly at the beginning of the Galician Land Bank. By monitoring its implementation, the project aimed to generate systematic information that enabled a continuous diagnosis of the program's running. The approach was process-oriented, less focused on the bank results per se but centered on the program's performance, aiming to identify key aspects (stronger and weaker points) in its implementation process. 
The structure and method of the monitoring work was based on four main fields of inquiry and analysis. Firstly, context depiction led to a general characterization of the Galician territory as well as broader backgrounds in so far as they play a relevant role in the bank's performance. The second field of inquiry concerned analysis of the bank's problem-solving framework, with its explicit goals, means, and strategies of implementation. Another field of inquiry entailed collecting and analyzing the bank's outputs. Through an IT information system, we received continuous information on how much land was being mobilized (on offer and demand) but also where that land was being mobilized, when, and to what rhythm.

Such monitoring also required acquaintance with the social profile of those most directly involved with the bank, a task carried out through the application of several methodological mediums. Surveys with the classic indicators (age, sex, occupation, etc.) were complemented by extensive use of qualitative methods, namely a wide range of interviews, observation, and attendance at assembly meetings. ${ }^{2}$ Through them an assortment of questions were addressed aiming at different groups that comprise potential as well as actual clients of the bank but also officeholders, managers and other relevant social actors related to this policy.

\section{Rural Galicia: past legacies to present challenges}

Galicia is a region located in the northwest part of the Iberian Peninsula. With $29,575 \mathrm{~km}^{2}$, it represents $6 \%$ of the total Spanish surface. There is a considerable diversity in its geography, coexisting in coastal areas, mountainous habitats with deep valleys, and flat lands. Climate is generally mild, with light temperature variations and abundant rainfall. Population numbers reach about 2,800,000 people, with a density of 93 inhab. $/ \mathrm{km}^{2}$ but with a highly irregular distribution; more than one-third of Galicia shows a population density per parish lower than 20 persons $/ \mathrm{km}^{2}$ and $64 \%$ of the population is concentrated in $10 \%$ of the territory (IGE).

According to the OECD methodology, Galicia is classified as "significantly rural," since $35 \%$ of its population lives in rural municipalities (less than 150 inhab. $/ \mathrm{km}^{2}$ ). On the other hand, such municipalities occupy $88 \%$ of the territory (MAPA, 2008). When looking at the use of land, afforested land accounts for $32 \%$ of the total area, while land devoted to agriculture represents about $25 \%$ of the Galician territory. Another $33 \%$ is occupied by scrubland, most of which results from abandonment of agriculture and/or burned forested surface. Within agriculture, cattle-farming is prominent, gathering roughly $60 \%$ of the UAA (MAPA, 2008). Such objective data more or less coincides with what is often evoked as the standard Galician landscape, a region of lush green pastures and entrenched rural traits.

2 Short surveys were attached to online applications that candidates were required to cover. Thirty-five extensive interviews were conducted from July 2007 to December 2008. 
Both portraits, statistic and emblematic, interesting as they may be, tell us little of what arguably is central in the Galician rural context: change and diversity.

Going back to the first half of the twentieth century we would unquestionably find Galicia deeply immersed in a rural sway. Unlike today, the demographic pressure in rural areas was very high and agriculture employed large numbers of the labour force. Thus, farmland was being extensively handled through family-oriented farms, a system which, following a historical tradition of property inheritance by subdivision within families (often with many heirs), produced a high degree of land fragmentation. Farmland, farmhouse, farming, and family were an indivisible unit and agriculture was still, to a large degree, operating within a self-sustainable socioeconomic model. Equally relevant were the high levels of poverty and illiteracy that afflicted rural Galicia, along with lack of health and education services, communications, and other such commodities. This entire scenario existed within a dictatorial political context that would last well into the 1970s. Such a regime, incidentally, was notoriously interventionist when it came to expropriating land or enforcing rural policy measures.

The following half-century brought profound transformations across Europe, leading to the booming of some industrialized centres and driving agriculture through momentous shifts in many of its social, economic, and technological facets. However, the pace and impact of such changes have been considerably different in different contexts, and for that matter experts make distinctions between those regions with higher levels of intensification and specialization and the so-called marginalized regions (FAO, 2006). In Galicia such wide transformations had the effect of a massive rural exodus to industrialized areas, both inside Spain or to other European countries. Meanwhile, the rising power of world markets left agriculture open to a competition mode, whereby traditional self-sufficient systems or low-yielding farms have hence little or no value and therefore bleak survival expectancy.

There seems to be little doubt that a massive rural emigration coupled with the demise of a deep-rooted model of farming shaped the profound transformations of the Galician territory. However, a system that has served as a society's keystone for countless years cannot quickly vanish. The remnants and adaptations that have endured since then form a mosaic that gives Galician's rural world its intrinsic singularity. Overall, we believe such legacy contributes to the main challenges but also potentials in land management. Within the complexity of this background, it is possible to highlight two issues that correlate directly to land banking: land tenure and land structure on the one side and land mobility on the other; both will be seen in context.

Due to historical processes, today property in Galicia is largely under private hands and highly fragmented in its structure. Further information on this depiction might prove eloquent. When dealing with land fragmentation distinct situations emerge; Van Dijk (2003) distinguishes three main facets of the land fragmentation phenomenon. Firstly, ownership fragmentation relates to the great number of land owners and/or the minute surface of land they own. In Galicia there are more than 1.6 million rural landowners, an amount equivalent to $60 \%$ of its inhabitants. This represents 1.7 ha per owner (DGC, 2007). 
The second modality refers to land use fragmentation, taking into account the number of users that may or may not own all or part of the land that they manage. Despite the fact that high ownership fragmentation can be mitigated at use level (few farmers managing land owned by a larger number of owners) in Galicia there are catchy figures to consider as far as the owners/farmers gap is concerned: 1.6 million versus 100,000 (DGC, 2007; INE, 1999). The third and most classical modality of fragmentation refers to the physical structure of the parcels when these are small. Normally it is accompanied by a significant grade of dispersion/distance among parcels belonging to one owner. Again, in Galicia the average 1.7 ha per owner is split into 7.7 parcels, which equates to a regular-size plot of 0.23 ha (DGC, 2007; INE, 1999). All of these values suggest that Galicia generously fulfils the multiple requisites of the fragmentation verdict.

To understand land mobility it is useful to keep in mind its social counterpart, which could be called people's mobility. In Galicia, like other regions in Europe, the number of people occupied in the agricultural sector has not stopped falling (declining 77\% from 1985 to 2005). Despite such tendency, it is worth noticing that this region still shows relevant rates of employment in the sector (11\% of total occupations in 2005), more than double the average for Spain (MAPA, 2008).

The massive rural exodus has had several layers of consequences in rural life. Most obviously, a large number of farms stopped their activity. Similarly, many of the land owners (or their heirs) do not actually live in rural areas. There came to be an estrangement, tangible and intangible, of proprietors from their lands, a process that left a notoriously aged segment of landowners as direct managers of their property, and with many of the younger heirs today - still opting to abandon agriculture. In certain regions, the demographic profile of the population is so unsustainable that some communities are deemed extinct. Not surprisingly, land structure in such areas often mirrors the same bleak scenario.

There is consequently a close link between land fragmentation, land mobility, and people's mobility. Studies have shown that the majority of plots liberated from former farming were not transferred to other farms; instead they have become either abandoned or used for non-agrarian purposes. This phenomenon is closely associated with land use change in Galician territory. What was previous farming land has given way to a significant forestation activity, a typical solution for retired farmers or their heirs. Concurrently, due to a lack of land planning policies, agricultural land has also been under pressure from real-estate interests which have effectively mobilized land sale but not in favour of an agricultural land market (López Iglesias, 1996).

Unlike other European regions, renting land to other farmers after the closure of farm activity has not been a common practice in Galicia; research reveals that $87 \%$ of farm surface is owned by the farmer, which means that official tenancy rates are very low (Ónega et al., 2006). The reasons for such reluctance are often invoked as a generalized fear amongst many landlords that through a legal contract the tenant might gain, in time, property rights over use, forcing the owner to resort to judicial means. There are also other insecurity-related issues, such as the guarantee of charging the rent or recovering the parcel in good conditions. It is interesting to 
note, however, that ceding land plots by verbal agreement to neighbours and/or family members who remain in the owners' ancestral village is nevertheless a very common practice in Galicia. Despite such patent occurrence, accurate information attesting how much land is under such informal agreements is inexistent, probably expressing a disposition which finds little or no value attached to transactions that cannot be rated by market standards. ${ }^{3}$

This leads us to ponder over non-economic considerations, a kind of syndrome that is often quoted when searching for reasons to explain the lack of will to transfer land in Galicia (López Iglésias, 1996; Ónega et al., 2006). It is mentioned that land owners prefer to maintain their properties as "saving capital" which assures a sense of protection in times of need. Other issues relate to land as patrimony: land as inheritance, as prestige, and a hub of emotional attachment. The brief inventory of such factors in the literature portrays a superficial knowledge of the subject but also seems to imply that the above conditions are not unlike residues of archaic attitudes that create obstacles for the successful rationale of market mobilization.

Non-economic considerations is a tag that tries to express less tangible issues behind the lack of agrarian land mobility, that is to say, a broad field of representations, opinions, and values held by individuals who also happen to be landowners. Through this perspective, the unwillingness to formally rent or sell land might be understood not so much as irrational resistance but instead an interesting strategy to cope with the acceleration of social transformation that has hit Galicia with all its weight.

Resistance to establishing a legal rent in favour of making an informal deal serves as a good example of how different rationalities can be taken into consideration when understood in relation to their social context. Firstly, one verifies that the majority of landowners who are in a position to decide upon the fate of their lands (with the average profile of an aged retired farmer) have incorporated a whole legacy of disempowerment of which a low instruction level is one of the most obvious consequences. ${ }^{4}$ Thus, legal documents are obscure and often menacing and it is not surprising that most of the land owners have felt much more insecure and unprotected by an official document than by a verbal agreement with relatives or neighbours, with whom a code of behaviour is tacitly shared. On the other hand, it might be plausible to consider that if one cedes or lends land to close relations one feels closer to the original status of ownership than releasing rights of use by binding juridical terms with strangers.

To be sure, informal contracts fall within a logic that is basically alien to production or economic interests. The way in which land management deals with such issues can actually be quite revealing of the paradigm that still rules over the policy implementation strategy. This brings to mind the ongoing discussions of power

3 Fortunately there was a recent reverse on this trend, with ongoing research being done on the interaction between property and land use (see Laborate, http://laborate.usc.es/en/welcome.html).

4 An objective and/or subjective condition of disempowerment is a widespread trait of peasantry, a fact thoroughly established in rural studies (Shanin, 1987 [1971]). 
and rationality in planning. In this field, it is common to consider a shift from approaches supported by a sweeping, instrumental rationality in charge of engineering social life to more recent approaches which take into account various forms of rationality. Citizen involvement in the planning process goes together with the questioning of what kinds of planning and rationality particular contexts demand (Alexander, 2000). In the Galician case, such social arrangements over property can remind us that land is not just a means of production or a market asset but is also and foremost the very fabric upon which social ties are woven between people and places. Land is thus a multilayered, multidimensional reality where a continuous construction of identity, history and relationships takes place.

It is also possible to appreciate the sound rationale, more or less self-aware, behind the impetus to "keep land for times of need." Again, superficial observation will have to cover the lack of any systematic study on the fact that a very large number of families in Galicia directly or indirectly make use of a backyard garden to support the household food budget. ${ }^{5}$ In face of the recent global economic oscillations and uncertainties that have also left their warnings in Galician society, land asserts its value as a resource backup to which people are known to resort. Too this end, it is not merely coincidental that huge plots of land are being bought as sound financial investments by wealthy operators in the world market. Arguably, the difference in scale might make the comparison seem ludicrous but the sheer pragmatic benefits of receiving the yields of the small kitchen garden are not to be dismissed, as surely many a Galician profiteer might attest. If we further add the intangible values such as "home-grown", "trustworthy", and "of quality" - increasingly popular in the social value scale, then grandmother's Sunday basket becomes a real asset. In many ways, small in Galicia is quite beautiful.

This overview of rural Galicia informs us of dramatic changes that have revealed a process through which Galician society has passed from an economy of self-sufficiency to one which is either dual or fairly integrated in the market. Today, as Galician anthropologist Gondar remarks, we come to one complex formation, where modern economic and social structures still mingle with past heritages, not just on the material surface, but also at the level of mental structures and cultural tools (Gondar Portasany, 1993).

No doubt that part of this legacy translates into deficits in land structure, lack of land policy instruments, and a civic disempowerment that can account for severe problems in the rural world and consequently in farm land mobilization. Considering the kind of trends which only seem able to answer to economic demands and which plainly benefit enlargement and other related rationalities, past legacies are no more than hindrances. However, there is an established research on farming systems which reveals the complexity, diversity, and rationality of much apparently untidy and unsystematic behaviours within such systems, particularly those less "developed" (Chambers, 2007). Accordingly, there 
are other inclinations and other criteria that foresee the revitalization of farming as a much more inclusive phenomenon, where social, cultural, and environmental values play a crucial role. Seen from this perspective, the remains of the past are not all easily dismissible.

All of the above makes way for considering the Galician land-related heritages and idiosyncrasies not only as obstacles to progress but also as fields of opportunities for a desirable future. In any case, a reasonable acquaintance with this rural context makes it clear that any political instrument that wishes to tackle land mobilization in Galicia has a real handful to deal with.

\section{Bantegal}

In 2007 the former Galician government developed specific measures in order to promote the mobilization and use of agricultural land, one of the most noticeable being the creation of the Galician Land Bank (GLB). Such policy stems from a body of legislation which launches a set of different but interrelated approaches. On the one hand, it shapes land banking in legal terms while it simultaneously establishes a penalty regime in which the administration can sanction those plots of land which are abandoned within "areas of special agricultural interest", as designated by law. This set of complementary measures, fairly in accordance with a carrot-and-stick approach, structures the foundation grounds of Bantegal, the public company responsible for managing land banking in Galicia.

Despite variations, all land banks seem to partake of the same principle of operation: an inflow of properties, an intermediate management, and outflow of properties. Typically, inflow is mainly based on acquisition of lands while the outflow relies both on acquisition and leasing procedures or similar actions (sales at market prices, auctions, direct distribution, long-term leasing, and/or other mechanisms). Very much in response to its context the GLB came up with its own configuration giving it some peculiar features that set it slightly apart from its European counterparts. These differences are particularly visible in the procedures through which properties are transferred. The GLB, despite being legally able to work through mechanisms of exchanging ownership in a buying and selling model like other land banks, operates mainly through a leasing model. With Bantegal assuming the role of intermediate manager, it works through renting contracts between landowners and tenants. In other words, it swerves from dealing with land ownership in favour of managing the exchange of rights of land use.

Such configuration responds emphatically to the circumstances and determinations of its social context. The bank mentors were well aware that in Galicia there is no land market tradition as such, together with the fact that the will to sell land runs low, while land prices are particularly high, even if land is uncultivated or abandoned. On the other hand, mobilizing land through a buying and selling model implies having considerable financial strength - a treat that few administrative bodies can claim for themselves. 
By working as a promoter of land leasing contracts through a mediator's role, the bank aims to mobilize land with lower expenditure while simultaneously veering to accommodate the Galician land owner's unwillingness to sell land. Nevertheless, as a land policy, the GLB meddles in a very sensitive social asset and therefore great efforts have to be made to ensure that the message of confidence is passed on. ${ }^{6}$ By invoking contract assurances that both sides may rely on, it offers convincing guarantees to the owners of not losing ownership over land, being paid according to the leasing contract, as well as recovering the property in normal conditions for its use after the contract has ended. Tenants, on the other hand, may rely on a preset minimum period of rent of five years, an advantageous guarantee for farmers who wish to implement medium-to-long-term investments.

Bantegal is not only an intermediary but also the prime promoter of land mobilization policy and as such it has to rely heavily on information and communication. For that reason it acts as the central point of contact between supply and demand, facilitating the transmission of information concerning land for rent. For this purpose it has been using a new GISWeb tool, developed in collaboration with local universities. ${ }^{7}$ This tool allows public access through which any potential client can offer his or her parcel to the bank. Potential clients can also get acquainted with all available parcels and begin procedures of land submission. Apart from this web tool, considerable resources have been assigned to promote communication through classic public campaigns and media coverage, in an effort to divulge the policy and win the public's sympathy.

In comparison with other land banks, GLB also displays some differences concerning the employment of land to be transferred. Although land bank instruments were first used in relation to agricultural ends similar to those required in Galicia, their scope of action has spread to other areas with spatial impact, with environmental or other specific social aims. GLB, despite allowing legal grounds for a variety of uses, has until now assumed an exclusive dedication to agricultural ends.

To conclude this general characterization, it is relevant to consider that land banking as a land management process can imply different arrangements as far as the participation of social actors is concerned. The GLB operates through a public company which can be considered an extension of the regional ministry of agriculture, and like similar administrative bodies in Galicia it does not include in its foundations the presence of other social partners, private or otherwise. However, Bantegal has been building collaboration with other actors not directly related to its staff, such as local universities, agrarian labour unions and other administrative departments. Nevertheless, the inclusion and participation of their most direct stakeholders (potential as well as actual clients) is yet to be developed.

Today, as before, the relationship between private and public spheres in land management is, in many ways, a very relevant topic. In Galicia, we have seen that a

6 Such sensitivity is well attested by the way in which the land bank issue was used during Galicia's last election race, when the bank was mentioned as an example of threat and landowners were warned about a covert attempt by government to expropriate land and render it public. Land information system of Galicia (www.bantegal.com/sitegal). 
majority of land is under private property and in a situation which eludes public control. Galicians, that is to say landowners, have inherited a burdensome legacy of state interventionism coupled with social destitution and a relationship with their rural background that carries contradictions in the way it plays with identities and affections. Land banking wishes to mobilize land in order to contribute to a dynamic rural world. To that end, mobilizing land manifestly leads to the need for mobilizing people. Such pair of goals provides new grounds and high challenges for this policy's capacity in developing mobilization in its fullest meaning.

\section{Articulations}

The relationship between the GLB and its context can be examined in the ways this policy answers its society's requests and in turn is faced by challenges posed by the Galician territory. To date, the bank has been able to mobilize land (1,636 plots of land) and thus bring about its main operational purpose. ${ }^{8}$ Beyond such immediate achievement, the sheer configuration of its modus operandi is a creative accomplishment insofar as it has dodged meddling in the land ownership structure, instead finding new tenure arrangements to mitigate the effects on land use fragmentation in agriculture. Overall, the policy sought to find an agile and soft intervention to tackle a complex set of land issues where clearly a general laissez faire crowned by market self-regulation has not produced satisfactory results as far as agriculture is concerned.

Given its characteristics, the GLB must rely on a balance between land that is given in and land that is requested, that is to say the initiative of both tenants and landlords. In other words, the need to mobilize land goes together with the need to mobilize people. In that sense it does not quite fulfil the quoted "benefits" of conventional land banking whereby "a government does not have to manipulate or control actors but can more directly change land ownership relations within a certain area" (see above). This means that the GLB cannot but take people into account, and ignores them at its own peril.

So far, demand seems to run smoothly as farmers have been presenting requests in generous numbers. The advantages of farm enlargement, one of the key notes of the bank's doctrine and campaign, have had clear recognition from farmers. Amongst other benefits, several of the European subsidies reward size in their criteria, and across interviews such rewards were frequently mentioned by farmers. Interestingly, roughly at the time the GLB was launched, fuel as well as fertilizers and animal feeds hit skyrocket prices, opening general debates about market regulation and import policies. For several farmers these events were the trigger to engage with the GLB discourse which claimed that by enlarging their territorial base, farms could reduce production costs, particularly in the case of cattle owners who can grow their own fodder through the attainment of extra land. For many of these farmers this 
option implies a departure from being highly market-dependent, a departure that interestingly harks back to that spurned but all-familiar traditional farming system, which then seems to lose some of its absurdity.

Landowners, on the other hand, present greater challenges in the mobilization scheme. ${ }^{9}$ In this case, and despite the possibility of receiving rents, financial motivation does not seem to stir large numbers of people to knock at Bantegal's door, a fact often asserted in interviews. Amongst a series of inertia-provoking factors (like family inheritance clarification, prospects of managing paperwork, etc.) there is also the already-mentioned heritage of civil disempowerment which has resulted in avoidance and/or suspicion towards the state administration, acutely so when it emits policies that impact on land rights. As previously noted, the legislation behind GLB has legal provision to apply penalty regimes in order to push landowners to lease lands within the perimeter of areas of special agricultural interest which are deemed neglected, but the political hazards of such a course of action clearly advise caution in its enforcement. Accordingly, the strategy has been to rely on soft interventions via public campaigns giving away abundant amounts of information and popular merchandise.

This fairly conventional approach portrays a tactic whereby members of the public are taken less as stakeholders and more as potential clients, that is to say, passive subjects in need of objective information and/or persuasion strategies. There is, however, the possibility of transforming this course of action and raising the critical awareness of power relationships and potential source of distortions in communication (Habermas, 1984; Collins and Thomas, 2003). From then on, a variety of approaches are available to mobilize stakeholders beyond sticks, carrots, and sermons, and which involve methods of participation and mutual cooperation. On the other hand, Galicia is a region which accommodates in its modest perimeter a surprising variety of social as well as biophysical landscapes that call for local, flexible, and human-scaled intervention. All of the above idiosyncrasies seem a challenging but overall appropriate field for change, distinct from the institutionalized and conventional top-down, centre-forward approach.

In the GLB credo, there is an explicit emphasis on improving land structures, particularly focused on size enlargement and with sound argument, given the average area of plots left by the historical fragmentation process. That very idea is expressed in public statements concerning policy goals, as a tool conceived to "reform structures in order to bring about productive units (farms) of good proportions and maintain a dynamic rural space". ${ }^{10}$

However, it is clear that sustainability of the rural space requires more than efficient land use policies affecting rex extensa. In fact, once they are taken in context, land reforms cannot be realistically conceived if not integrated in a wider social fabric.

9 Many of the rented plots (91\%) are actually being generated via public lands which are at the bank's disposal. Ceding deals represent $42 \%$ of the total number of contracts. More relevant than discrepancy between supply and demand is the fact that private land being put at the bank's disposal is clearly less attractive to demand than the public land available, probably due to the size and other structural advantages of the latter.

10 In press statement, last consulted 25/10/2009, http://www.agroinformacion.com/ 
Thus, sustainability poses many other challenges to policy makers, such as providing or guaranteeing relevant levels of social equity and welfare, as well as integrating environmental standards within their policies. To be fair, large sustainable goals clearly stretch beyond the reach of land banking, but such limits should not prevent the questioning of the presence of such goals within land banking confines and possibilities.

An overview within this arena leads us, in the first place, to consider the presence of environmental guidelines in this policy. So far, such precepts in the GLB have had a kind of collateral existence since they are referred to mainly as positive outcomes of the policy application, for example, the benefits of minimizing the risk of wildfires as a possible result of converting uncultivated abandoned plots of land. Land banking, however, has certainly the potential to enlarge and put into practice broader environmental standards, making it a cross-section concern in its modus operandi. What seems to be the case is that behind the conceptual creation of such initiative there is a guiding and largely implicit principle that environment goals and agricultural productive ambitions are somehow opposing drives which can only meekly overlap. Of course this can and often is the case if agriculture is taken as a one-dimensional and set-apart affair, particularly if a maximum-yields-at-any-cost approach is allowed to thrive unquestioned.

Interestingly, in the environmental arena there seems to be some degree of harmonious agreement between the underlying outlook of the policy and that of its public, particularly of those many Galicians who partake of a rural background, and for whom land's value is closely associated with its conventional productive function. One should not, however, rush to establish plain correspondences between value and production. A thoroughly cultivated plot of land is a highly symbolic environment where the social value of production must be considered on a par with its economic value. To that effect, interviews with landowners as potential bank clients show that their motivations to concede land have less to do with economic gains and more to do with the intangible value related to the prospect of seeing (their) land being tended, to the extent that cultivation of land is here akin to a sense of caring (while unfarmed or abandoned land has its own share of connotations). Research has attested that the social symbolic value of well-tended fields exists across a range of countries and farming landscapes (Burton, 2004a). Similarly, the idea of increasing production with its high social value is present in agricultural policies but also plays a part in the very ethos of being a good farmer and consequently is an important feature in contemporary farming culture (Burton, 2004a; Wilson, 2001).

This match between the GLB and the general public, particularly amongst Galician farmers, also points to an idea of farming which is more associated with the traditional function of vertical production and less with newer horizontal modalities - a more local and multipurpose agriculture. ${ }^{11}$ This new model echoes Ulrich Beck's

11 Interesting and possibly revealing is the existence of different words to designate the concept of farm (a phenomenon common to all Iberia). In Galicia, the farm is referred to as an "agricultural exploitation" or a "productive unit", a semantically eloquent terminology that is used and reproduced by academics, technicians, and policy makers alike but rarely employed by farmers or indeed any other segments of society. 
forewarning, according to which "we are therefore concerned no longer exclusively with making nature useful or with releasing mankind from traditional constraints, but also and essentially with problems resulting from techno-economic development itself" (Beck, 1992).

Without falling into the debate of the current paradigm change in agriculture between the so-called withdrawal from productivist to postproductivist modes, there can be little doubt that environmental policies push farmers towards new roles (e. g., conservation agents, value adding producers, leisure managers) and away from previous intensive agricultural producers. Resistance to change is not surprising because the fundamental references of farmers are being poked at, and often economic compensation is not enough to overcome established practices, an understandable reaction if one takes into account that many practices that have high symbolic value also produce economic benefits, although they should not be reduced to them (Burton, 2004a; Coimbra, 2005).

In the GLB, environment, social equity and welfare concerns are mainly manifested through a set of criteria with which Bantegal passes on land to petitioners in the case of competition; that is to say, if more than one farmer is interested in a particular plot of land, there are certain factors which bring advantages to the petitioner. These include being a young farmer, female, and settling in deprived regions, amongst others. The suitability of such procedure is, in any case, confined to a passive approach. Other proactive measures have been taken but were not planned as such, and thus must rely on the personal capacity of the manager to foresee them, and implement them along the way, along with the volatile political support that might see them through.

Large goals that make up for a sustainable rural environment are part of the spectrum of questions and answers that circulates between this land managing policy and its territory, even when the issues remain largely implicit. Interviewing different actors involved in this governance initiative - from policy makers to administrative officials and cattle farmers - has unveiled the contours of what farming and the rural world is expected to be according to different actors. Simultaneously it has shown that such an aspiration, central and conditioning as it may be in shaping attitudes and direct actions, remains mostly undisclosed. The task of articulating stakeholders' points of views cannot but suggest that a fitting subject for communication could well run through the lines of promoting a dialogue about what model of agriculture stakeholders wish for. The utopian oriented discussion should not mask the pragmatic ends of such an exercise nor should it be hindered by claiming context impediments such as "Galician farming can never reach the peaks of intensive production of other places". It might not, but more importantly does it want to? What manner of drum beat should it follow? There seems to be enough ambiguity coming from the guidelines and subsidies of European policies to maintain replications at the local level. As we have seen, Galicia's contextual circumstances, as complex as they may be, are not solely hindrances. Above all, they should not paralyze all manner of exercises of social creativity that attempt to break through the business-as-usual of the establishment. The creation of land banking, the Galician way, can be regarded as proof of this. 


\begin{tabular}{|c|c|}
\hline \multicolumn{2}{|l|}{ Problem-solving framework } \\
\hline Problem or issue & Land fragmentation and land abandonment. \\
\hline Main goals and priorities & $\begin{array}{l}\text { Revitalize agriculture by means of improving } \\
\text { productive units. }\end{array}$ \\
\hline $\begin{array}{l}\text { Conceptualization/model of problems and their } \\
\text { mechanisms and causes }\end{array}$ & $\begin{array}{l}\text { Dormant (agricultural) land market. Historic legacies } \\
\text { that left small, fragmented land plots mainly in private } \\
\text { hands, increasingly abandoned. Non-economic } \\
\text { reasons for keeping plots (deemed economically } \\
\text { unfeasible for agriculture). }\end{array}$ \\
\hline $\begin{array}{l}\text { Solution complex/means and methods to manage } \\
\text { problems }\end{array}$ & $\begin{array}{l}\text { Establish agricultural areas (and sanctions on } \\
\text { abandoned land). Creation of bank and land-use } \\
\text { policy. Leasing strategy. Campaigns to encourage land } \\
\text { mobilization. Define farmers and land-owners as } \\
\text { clients. Selection criteria for leasing to promote } \\
\text { development strategy (young farmers, women, etc.). }\end{array}$ \\
\hline \multicolumn{2}{|l|}{ Social organizational complex } \\
\hline Responsible/authority agents & $\begin{array}{l}\text { Bantegal (delegated responsibility and authority by the } \\
\text { state). }\end{array}$ \\
\hline Decision-making forms and procedures & Multi-stakeholder participation is weak. \\
\hline Knowledge & $\begin{array}{l}\text { Expertise and knowledge requirements. } \\
\text { Administrative/bureaucratic knowledge (including } \\
\text { agricultural extension officers). Technical/scientific } \\
\text { knowledge (GISWeb, economy experts). Marketing } \\
\text { campaigns experts. Assessment experts. Local } \\
\text { knowledge. }\end{array}$ \\
\hline Actors most directly affected & Farmers and owners of land. \\
\hline
\end{tabular}

\section{Results}

A summary of the main results can best be perceived by displaying several of the identified elements into the architecture of governance framework, as shown in table 1.

\section{Conclusions}

Land banking in Galicia was born out of the initiative of resolving structural land problems, particularly that of land fragmentation, with the purpose of revitalizing and making viable agriculture in the Galician rural territory. A context-oriented approach shows that structural land problems such as fragmentation and land abandonment are crucially linked to an assortment of matters such as multilevel political rural guidelines and subsidies, and international market oscillations, but 
also rural exodus and local legacies of peasantry disempowerment, amongst other issues. All of this constitutes a complex scenario in which historical local legacies and global influences set the crossroads of present-day rural Galicia. This is the dynamic context to which land banking is inevitably related.

Deficiencies in agricultural land structure and land mobility are the more tangible aspects of social abandonment or neglect of the rural world, a scenario that presents serious challenges to a whole program of measures and not land banking alone. To this end, land banking may achieve its full potential when it can be integrated into a broader project with the necessary clout to deal with what lies behind the continuous rural exodus, territorial planning deficits, and competing forestry farming interests, amongst other thorny intervention issues.

It has been highlighted that one of the main peculiarities of this policy in relation to other European banks is that, unlike its counterparts, to achieve land mobilization the GLB does not rely on mechanisms of exchanging ownership in a buying and selling model, but instead operates through a leasing model. In this way, the bank assumes the role of intermediary manager between landowners and tenants. Such peculiarity can be taken as a direct response to its context insofar as it deals with the specific circumstances found in Galicia, but which are not exclusive to its borders; that is to say, it circumvents the problems of a dormant land market, added to a state's budget that cannot afford playing a strong hand in the land market bid. Similar challenges and possible solutions are to be found just across the border. Portugal has very similar land structures and social conditions, particularly in its northern regions and it is therefore not surprising to find that policy measures, akin to the pioneering GLB, are also under way. ${ }^{12}$

The analysis of this governance initiative has pointed out the benefits of establishing stronger links between those clearly defined operational objectives such as land mobilization (with land contracts as their explicit results) and those larger goals that vaguely address the sustainability of the rural world. Considering the latter, we have stressed the possibility of considering a multipurpose integrative model of agriculture and stakeholders' room for participation. In the first case, we have highlighted how environmental guidelines play a modest role in the policy, suggesting that its view of the agricultural vocation seems to be still influenced by a productivist paradigm which has difficulty integrating environmental, social, and productive ends into one single approach. Similarly, such a political stance seems to be in undemanding accord with the general public, particularly amongst Galician farmers, for whom a change into a new model of agriculture is most likely challenging.

Within the sphere of participation, it has been pointed out that there is space for improvements, particularly in relation to the channels of communication between the public and administration. It is here that the historic weight of civic disempowerment, together with a long-standing tradition of state interventionism, shows its full weight and consequently raises both the need and the difficulty in establishing new governance approaches. These might entail extending 
and structuring efforts already engaged in reaching the Galician territory, taking into account the variety of its different needs. Overall, in this land banking system, people's participation has quite a lot going for it since the need to mobilize land goes hand in hand with the need to mobilize people. To this end, it has been suggested that methods that go beyond the conventional carrot-and-stick approach are both available and desirable.

Innovative approaches in communication can also be extended within the administration, fortifying the already given first steps in creating links with other state bureaus such as those of forestry, conventionally assumed to be outside agricultural interests and which in Galicia occupy a very relevant place in rural territory. To conclude our observations it is fitting to suggest the value of further fostering full processes of evaluation procedures designed and understood as useful learning systems, particularly appropriate in times of rapid transitions, uncertainties, and challenges in land management.

It has been stressed throughout this work that close attention to the Galicia's rural context beyond its most immediate surface shows a rich changing mosaic in which modern economic and social structures mingle with past heritages. Such a context, complex as it may be, offers land banking plenty of material to exert further creativity and willpower in integrating private and public interests, environment and farming goals, as well as global and local scales along past, present, and future landscapes.

\section{Acknowledgments}

This study was financially supported by Fundação para a Ciência e a Tecnologia. The author would like to thank reviewers for constructive and courteous criticism of an earlier version of this paper. Finally, personal thanks are due to those Galician colleagues and friends from Laborate who contributed decisively to the undertaking of the research summarized here.

\section{References}

Alexander, Ernest R. (2000), “Rationality revisited: planning paradigms in a post-postmodernist perspective", Journal of Planning Education and Research, 19 (3), pp. 242-256.

Beck, Ulrich (1992), Risk Society. Towards a New Modernity, London, Sage Publications.

Bemelmans-Videc, Marie-Louise, Ray C. Rist, and Evert Verdung (1998), Carrots, Sticks and Sermons. Policy Instruments and Their Evaluation, New Brunswick, NJ, Transactions Publishers.

Boletín Oficial del Estado (2007), Medidas Administrativas e Tributarias para la Conservación de la Superficie Agraria Útil y del Banco de Tierras de Galicia, available at: http://www.boe.es/boe/dias/2007/07/18/pdfs/A31238-31251.pdf

Bouhier, Abel (1979), La Galice. Essai Geographique d'Analyse et d'Interprétation d'Un Vieux 
Complexe Agraire, La Roche-sur-Yon, Imprimerie Yonnaise.

Burns, Tom R., and Helena Flam (1987), The Shaping of Social Organization. Social Rule System Theory and Its Applications, London, Sage Publications.

Burns, Tom R., and Christian Stöhr (s/d), "Power, knowledge and conflict in the shaping of commons governance: the case of EU Baltic fisheries", International Journal of the Commons, under review.

Burton, Rob J. F. (2004a), “Seeing through the 'good farmer's' eyes: towards developing an understanding of the social symbolic value of 'productivist' behavior", Sociologia Ruralis, 44 (2), pp. 195-215.

Burton, Rob J. F. (2004b), "Reconceptualizing the 'behavioural approach' in agricultural studies: a socio-psychological perspective", Journal of Rural Studies, 20, pp. 359-371.

Carreira Pérez, Xoán C. (2009), “O minifundio: ¿residuo do pasado ou proxecto de futuro?", Vieiros, Galiza Hoxe, available at: http://www.vieiros.com/columnas/opinion.php?id=618

Carson, Marcus, Tom R. Burns, and Dolores Calvo (eds.) (2009), Paradigms in Public Policy. Theory and Practice of Paradigm Shifts in the EU, Frankfurt/New York/Oxford, Peter Lang Publishing Group.

Chambers, Robert (2007), From PRA to PLA and Pluralism. Practice and Theory, Brighton, The Institute of Development Studies.

Coimbra, Elsa (2005), O Regresso do Monte. A Relação Sociedade Natureza na Comarca dos Oscos, Lisbon, ISCTE - Lisbon University Institute.

Collins, Joanna, and Gillian Thomas (2003), "Carrots, sticks and sermons: influencing public behaviour for environmental goals", available at: http://www.demos.co.uk/files/CarrotsSticksSermons.pdf

Corbelle Rico, Eduardo, and Rafael Crecente Maseda (2008), “Land abandonment: concept and consequences", Revista Galega de Economia, 17 (2), pp. 47-62.

Crabb, John, et al. (1998), "Set aside landscapes: farmer perceptions and practices in England", Landscape Research, 23 (3), pp. 237-254.

Dickens, Peter (2000), "Society, space and the biotic level: an urban and rural sociology for the new millennium", Sociology, 34 (1), pp. 147-164.

DGC - Dirección General del Catastro (2007), Estadísticas Catastrales (online), available at: http://www.catastro.meh.es/esp/estadistica/estadisticas2.asp

DLG (2005), Land Abandonment, Biodiversity and the CAP, available at: http://www.ieep.eu/topics/agriculture-and-land-management/2005/06/land-abando nment-biodiversity-and-the-cap

Evans, Mick, et al. (2002), "Conceptualizing agriculture: a critique of post-productivism, as the new orthodoxy", Progress in Human Geography, 26 (3), pp. 313-332.

FAO (2006), "The role of agriculture and rural development in revitalizing abandoned/depopulated areas", 34th Session of the European Commission on Agriculture, Riga.

FAO (2007), Good Governance in Land Tenure and Administration, Rome, FAO Land Tenure Studies.

Freire, Dulce, Inês Fonseca, and Paula Godinho (eds.) (2004), Mundo Rural. Transformação e Resistência na Península Ibérica (Século XX), Lisbon, Edições Colibri. 
Fundación Caixa Galicia (2006), “A economía galega: informe 2005", available at: http://www.fundacioncaixagalicia.org/StaticFiles/Contenidos\%20Fundacion/CIEF/ Actividades/Economia\%20Galega_2005.pdf

García, Lupe, et al. (2008), “Contribuciones de las mujeres a la economía rural: caso de las mujeres de Lugo", CIFEX - Congreso Nuevas y Viejas Cuestiones de las Investigaciones de las Mujeres y del Género, Santiago de Compostela.

Garde Roca, Juan A. (2004), “La evaluación de políticas y su institucionalización en España”, GAPP, 30/31, pp. 11-21.

Gondar Portsany, Marcial (1993), Crítica da Razón Galega, Vigo, A Nosa Terra.

Habermas, J. (1984), The Theory of Communicative Action, vol. 1, London, Heinemann.

Harvey, Jacob (2007), "Social conflict over property rights", Land Lines, 19 (2), pp. 14-19.

Hengel, Paul G. H., and Charlotte Carlson (2002), “Enhancing learning through evaluation: approaches, dilemmas and some possible ways forward", paper presented at 5th EES Biennial Conference, Learning, Theory and Evidence, available at: www. europenevaluation. org

INE (1999), Censo Agrario de 1999, available at: http://www.ine.es

Ingold, Tim (1993), "The temporality of landscape", World Archaeology, 25 (2), pp. 152-174.

López Iglesias, Edelmiro (1996), Movilidad de la Tierra y Dinámica de las Estructuras Agrarias en Galicia, Madrid, Ministerio de Agricultura, Pesca y Alimentación, Secretaría General Técnica.

López Iglesias, Edelmiro (2000), “The Galician agricultural sector in the face of 21st century: an assessment of its recent changes", Revista Galega de Economía, 9 (1), pp. 167-196.

MAPA - Ministerio de Agricultura, Pesca y Alimentación (2008), Programa de Desarrollo Rural de Galicia 2007-2013, s/l, Ministerio de Agricultura, Pesca y Alimentación, Junta de Galicia, available at: http://www.mapa.es/desarrollo/pags/programacion/ programas/Galicia/Galicia.pdf

Mitchell, David, et al. (2008), “Evaluating land administration projects in developing countries", Land Use Policy, 25, pp. 464-473.

Morris, Carol, and Nick Evans (2004), “Agricultural turns, geographical turns: retrospect and prospect", Journal of Rural Studies, 20, pp. 95-111.

Naranco, Juan (1967). "La agricultura y el desarrollo económico español”, Cuadernos de Ruedo Ibérico, 13, pp. 6-31.

OCDE (1998), Adjusting in OECD Agriculture. Reforming Farmland, Paris, OCDE.

Ónega, Francisco, et al. (2006), “Instrumentos para movilizar las tierras agrarias en Galicia: percepción de los agricultores", VI Coloquio Ibérico de Estudios Rurales. El Papel de las Regiones en las Economías Locales, Huelva.

Ostrom, Elinor (2003), “How types of goods and property rights jointly affect collective action", Journal of Theoretical Politics, 15 (3), pp. 239-270.

Shanin, Theodor (1987 [1971]), Peasants and Peasants Societies, Harmondsworth, Penguin Books.

Soliva, Reto (2006), “Landscape stories: using ideal type narratives as a heuristic device in rural studies", Journal of Rural Studies, 23 (1), pp. 62-74. 
Thapa, Gopal, and G. S. Niroula (2008), "Alternative options of land consolidation in the mountains of Nepal: an analysis based on stakeholders' opinions", Land Use Policy, 25, pp. 338-350.

Van Dijk, Terry (2003), “Scenarios of Central European land fragmentation”, Land Use Policy, 20, pp. 149-158.

Van Dijk, Terry, and D. Kopeva (2006), "Land banking and Central Europe: future relevance, current initiatives, Western European past experience", Land Use Policy, 23, pp. 286-301.

Van Dijk, Terry (2007), “Complications for traditional land consolidation in Central Europe", Geoforum, 38, pp. 505-511.

Walford, Nigel (2002), "Agricultural adjustment: adoption of and adaptation to policy reform measures by large-scale commercial farmers", Land Use Policy, 19 (3), pp. 243-257.

Wals, Arjen E. J., et al. (2009), The Acoustics of Social Learning. Designing Learning Processes that Contribute to a More Sustainable World, The Netherlands, Wageningen Academic Publishers, available at: http://www.senternovem.nl/mmfiles/acoustics-digital\%20def_tcm24-290164.pdf

Wilson, Geoff (2001), “From productivism to post-productivism... and back again? Exploring the (un)changed natural and mental landscapes of European agriculture", Transactions, 26 (1), pp. 77-102.

Winter, Michael (1997), “New policies and new skills: agricultural change and technology transfer", Sociologia Ruralis, 37 (3), pp. 363-381.

Winter, Soren, and Peter J. May (2001), “Motivation for compliance with environmental regulations", Journal of Policy Analysis and Management, 20 (4), pp. 675-698.

Elsa Coimbra. Guest researcher in LUCSUS - Lund University, and researcher at CIES-IUL, Lisbon University Institute. E-mail: Maya8270@yahoo.com

\section{Resumo/ abstract/ résumé/ resumen}

A gestão de terras em contexto social: uma análise do Banco de Terras Galego

O banco de terras é um instrumento conhecido para lidar com uma variedade de assuntos relacionados com a gestão de terras, tipicamente incidindo no minifundismo. Para enfrentar os múltiplos desafios inerentes à fragmentação de terras, em 2007 lançou-se na Galiza uma inovadora versão de banco de terras. Tendo como base um projecto de avaliação, este artigo apresenta o Banco de Terras Galego a partir de uma contextualização social. Articular tal política ao seu contexto permite-nos entender de que forma este banco responde às condições e desafios sociais que tem por base. Os resultados revelam que esta modalidade galega de banco de terras é em grande medida uma resposta criativa face às vicissitudes do seu contexto histórico-social, mas que outros passos podem ser dados para reforçar este diálogo. Estes incluem conceber a agricultura como uma actividade mais polivalente e 
integradora, juntamente com a necessidade de incorporar abordagens mais participativas, capazes de mobilizar todas as partes interessadas.

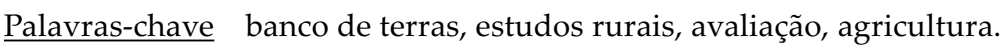

\section{Land management grounded in social soil: Galician land banking in context}

Land banking is a well established land management tool that has been used to tackle a variety of issues, most typically, land fragmentation. In 2007, an innovative approach to land banking was released in Galicia, northern Spain. Drawing from a monitoring project conducted on this initiative, this paper offers a description of the characteristics of the Galician Land Bank by grounding it in its specific social milieu. Articulating policy with context allows us to analyze how land banking simultaneously answers and is being challenged by its social conditions. Results reveal how land banking the Galician way is, to some degree, a creative answer to its contextual circumstances but that further steps might be taken to reinforce this dialogue. These include envisioning agriculture as a more integrated and multipurpose activity together with the need to incorporate more participatory approaches to mobilize stakeholders.

$\underline{\text { Keywords }}$ land banking, rural studies, evaluation, agriculture.

La gestion des terres en contexte social: une analyse de la Banque des Terres de Galice

La banque des terres est un instrument créé pour s'occuper des différentes questions liées à la gestion de la terre, en particulier concernant les minifundia. Pour relever les multiples défis inhérents à la fragmentation des terres, la Galice a lancé en 2007 une version innovante de banque des terres. En se basant sur un projet d'évaluation, cet article présente la Banque des Terres de Galice à partir d'une contextualisation sociale. Articuler cette politique avec son contexte nous permet de comprendre comment cette banque répond aux conditions et aux enjeux sociaux sur lesquels elle se fonde. Les résultats révèlent que cette modalité galicienne de banque des terres est en grande partie une réponse créative aux vicissitudes du contexte historique et social, mais que d'autres pas peuvent encore être faits pour renforcer ce dialogue. Il faudrait par exemple concevoir l'agriculture comme une activité plus polyvalente et intégratrice, ainsi que prévoir des approches plus participatives, susceptibles de mobiliser toutes les parties concernées.

Mots-clés banque des terres, études rurales, évaluation, agriculture. 
La gestión de tierras en contexto social: un análisis del Banco de Tierras Gallego

El banco de tierras es un instrumento conocido para lidiar con una variedad de asuntos relacionados con la gestión de tierras, típicamente incidiendo en el minifundismo. Para enfrentar los múltiples desafíos inherentes a la fragmentación de tierras, en 2007 se creó en Galicia una innovadora versión de banco de tierras. Teniendo como base un proyecto de evaluación, este artículo presenta el Banco de Tierras Gallego a partir de una contextualización social. Articular tal política a su contexto nos permite entender de qué modo este banco responde a las condiciones y retos sociales que tienen en su base. Los resultados enseñan que esta modalidad gallega de banco de tierras es en gran medida una respuesta creativa ante las vicisitudes de su contexto histórico-social, pero que hay otros pasos posibles para reforzar este diálogo. Estos incluyen concebir a la agricultura como una actividad más polivalente e integradora junto con la necesidad de incorporar abordajes más participativos capaces de movilizar todas las partes interesadas.

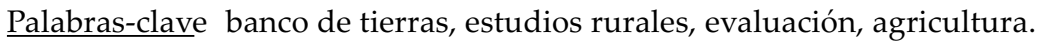

